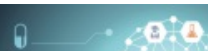 Chemical Education

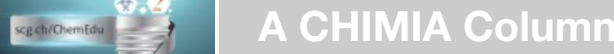 \\ Topics for Teaching: Chemistry in Nature
}

\section{Silicates, Aluminosilicates and Biogenic Silica}

\section{Catherine E. Housecroft}

${ }^{*}$ Correspondence: Prof. C. E. Housecroft, E-mail: catherine.housecroft@unibas.ch Department of Chemistry, University of Basel, BPR 1096, Mattenstrasse 24a, $\mathrm{CH}-4058$ Basel

Abstract: Silicate and aluminosilicate minerals are hugely important in the Earth's crust; this article introduces three mineral classes and describes the origins of biogenic silica.

Keywords: Aluminosilicate - Biogenic silica - Education · Silicate $\cdot$ Structure-property relationships

In an earlier Education Column, ${ }^{[1]}$ we described the assembly of the 3D-structures of ice and $\mathrm{SiO}_{2}$ using tetrahedral building blocks. We now extend this concept to silicate minerals and biogenic silica. Of the 118 chemical elements, only a few are abundant on Earth. $46.6 \%$ of the Earth's crust consists of oxygen, primarily in the form of oxides, carbonates, sulfates, silicates and aluminosilicates, while $27.7 \%$ comprises silicon compounds, mainly in the form of sand and quartz $\left(\mathrm{SiO}_{2}\right)$, silicates and aluminosilicates. Aluminium occurs in the Earth's crust to an extent of $8.1 \%$, largely as bauxite (a mixture of $\mathrm{Al}_{2} \mathrm{O}_{3}$ and $\mathrm{Al}(\mathrm{O})(\mathrm{OH})$ ) and aluminosilicates.

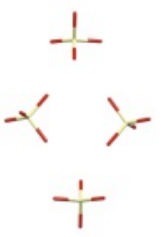

(a)

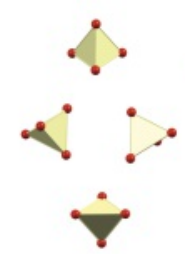

(b)

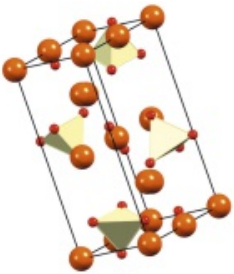

(c)

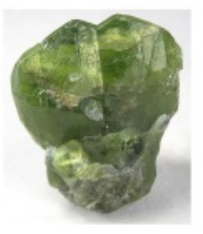

(d)
Fig. 1. Olivine, $(\mathrm{Fe}, \mathrm{Mg})_{2} \mathrm{SiO}_{4}$ contains discrete $\left[\mathrm{SiO}_{4}\right]^{4-}$ units shown in stick representation in (a), and in polyhedral representation in (b). (c) A unit cell of olivine showing $\mathrm{Fe}^{2+} / \mathrm{Mg}^{2+}$ (orange) and $\left[\mathrm{SiO}_{4}\right]^{4-}$ ions. Data: ICSD code 4353. ${ }^{[2]}$ (d) A piece of magnesium-rich olivine (by Rob Lavinsky, iRocks.com - CC-BY-SA-3.0, CC BY-SA 3.0, https://commons. wikimedia.org/w/index. php?curid=10138782).

Silicate minerals are divided into six classes according to their building blocks, and we consider three of these. The mineral olivine is an example of a nesosilicate and contains discrete $\left[\mathrm{SiO}_{4}\right]^{4-}$ units. The chemical formula of olivine is $(\mathrm{Mg}, \mathrm{Fe})_{2} \mathrm{SiO}_{4}$. The ' $(\mathrm{Mg}, \mathrm{Fe})$ ' formulation signifies that the mineral can contain $\mathrm{Mg}^{2+}, \mathrm{Fe}^{2+}$, or a mixture of $\mathrm{Mg}^{2+}$ and $\mathrm{Fe}^{2+}$ ions. Figs $1 \mathrm{a}$ and $1 \mathrm{~b}$ show the arrangement of four adjacent $\left[\mathrm{SiO}_{4}\right]^{4-}$ ions in crystalline olivine. The $\mathrm{Mg}^{2+}$ and/or $\mathrm{Fe}^{2+}$ ions are located between the $\left[\mathrm{SiO}_{4}\right]^{4-}$ tetrahedra with electrostatic interactions between the cations and anions. Fig. 1c shows one unit cell in crystalline olivine with the metal ions highlighted in orange. Mg-rich olivines have a green or yellow appearance (Fig. 1d) while Fe-rich olivines are brown or black. The pale green mineral peridot is gem-quality $\mathrm{Mg}$-rich olivine.

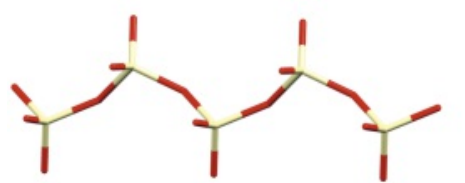

(a)

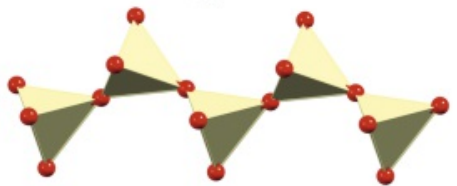

(b)

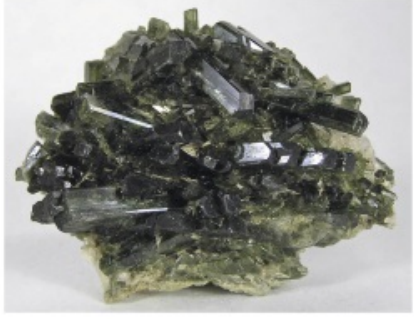

(c)
Fig. 2. Part of an $\left[\mathrm{SiO}_{3}\right]_{n}^{2 n-}$ chain present in diopside: (a) stick and (b) polyhedral representations. Data: ICSD code 9672 [2]. (c) Crystalline diopside (Rob Lavinsky, iRocks.com - CC-BY-SA-3.0, CC BY-SA 3.0 $<$ https://creativecommons.org/licenses/by-sa/3.0>, via Wikimedia Commons).

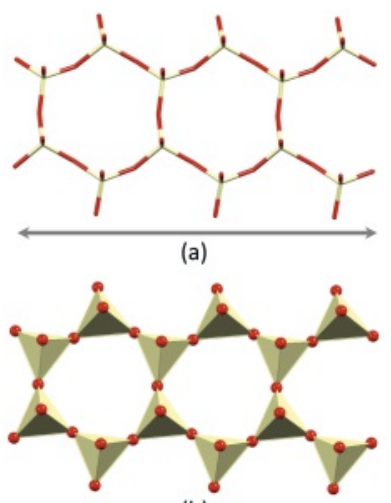

(b)

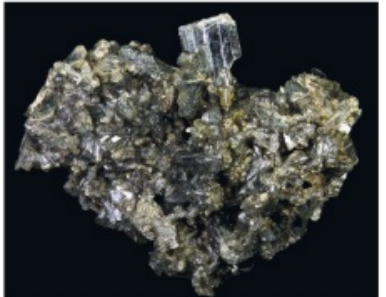

(c)
Fig. 3. Part of an $\left[\mathrm{Si}_{4} \mathrm{O}_{11}\right]_{n}^{6 n-}$ double-chain present in tremolite: (a) stick and (b) polyhedral representations. Data: ICSD code 46173 [2]. The arrow shows the direction of chain propagation. (c) Crystalline tremolite (Didier Descouens, CC BY-SA $4.0<$ https:// creativecommons.org/ licenses/by-sa/4.0>, via Wikimedia Commons).

In the $\left[\mathrm{SiO}_{4}\right]^{4-}$ units in olivine, each $\mathrm{O}$ atom is terminal and carries a 1-charge. Figs 2 and 3 demonstrate that if two or three $\mathrm{O}$ atoms per $\mathrm{Si}$ form bridges between pairs of $\mathrm{Si}$ atoms, the resultant building blocks are single $\left[\mathrm{SiO}_{3}\right]_{n}{ }^{2 n-}$ chains (Fig. 2) or double $\left[\mathrm{Si}_{4} \mathrm{O}_{11}\right]_{n}{ }^{6 n-}$ chains (Fig. 3). Silicate minerals containing $\left[\mathrm{SiO}_{3}\right]_{n}^{2 n-}$ or $\left[\mathrm{Si}_{4} \mathrm{O}_{11}\right]_{n}^{6 n-}$ chains are inosilicates and include the pyroxenes and amphiboles. The prefix ino comes from the ancient Greek îva meaning fibre-like. Typical pyroxenes are silicates of $\mathrm{Fe}^{2+}, \mathrm{Mg}^{2+}$ and/or $\mathrm{Ca}^{2+}$, for example diopside, $\mathrm{CaMgSi}_{2} \mathrm{O}_{6}$ (Fig. 2) and hypersthene, (Fe, $\mathrm{Mg}) \mathrm{SiO}_{3}$. Double-chains are characteristic of the amphibole minerals and an example is tremolite, $\mathrm{Ca}_{2} \mathrm{Mg}_{5} \mathrm{Si}_{8} \mathrm{O}_{22}(\mathrm{OH})_{2}$. Tremolite tends to exhibit long or column-like crystals (Fig. 3) or may have a fibrous habit. In this latter form, it is found as a component of asbestos which is a mixture of fibrous minerals and is well known for its health hazards. 


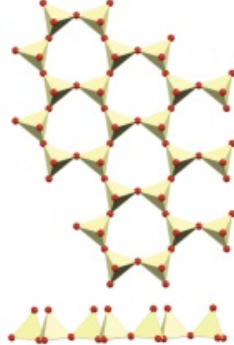

(a)

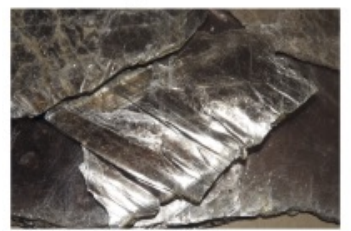

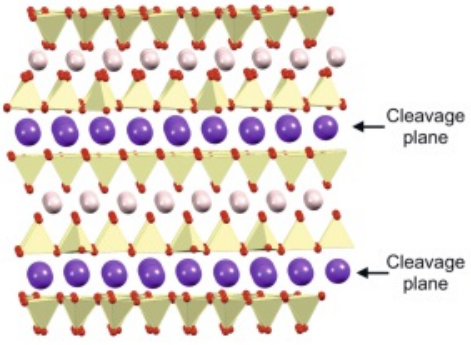

(b)

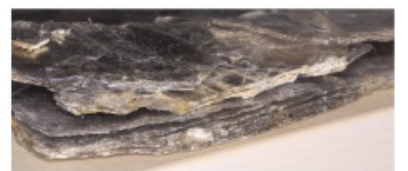

(c)

Fig. 4. (a) Part of a 2D-sheet present in phyllosilicates viewed from above and from the side. (b) Representation of the layer structure of muscovite mica. Data: ICSD code 74608 [2]. The sheets are in polyhedral representation, $\mathrm{Al}^{3+}$ ions in pink, and $\mathrm{K}^{+}$ions in purple; $\mathrm{OH}^{-}$ions are omitted. (c) Pieces of muscovite mica; micas cleave easily into very thin sheets. Credit: E. C. Constable 2020.

Increasing the number of $\mathrm{Si}-\mathrm{O}-\mathrm{Si}$ bridge units takes us from 1D-chains to 2D-sheets, and the sheet structure shown in Fig. 4a has the formula $\left[\mathrm{Si}_{4} \mathrm{O}_{10}\right]_{n}^{4 n-}$. An example is the mineral talc, $\mathrm{Mg}_{3} \mathrm{Si}_{4} \mathrm{O}_{10}(\mathrm{OH})_{2}$, which is soft and cleaves into thin plates. This is a lamellar habit. Notice in Fig. 4a that the $\mathrm{SiO}_{4}$-units within a single sheet all point in one direction giving one 'flat' surface. Talc is a member of the chlorite group of minerals, and chlorites and $m i$ cas belong to the class of phyllosilicates. The prefix phyllo comes from the ancient Greek $\phi \tilde{v} \lambda \lambda$ ov meaning leaf, and describes the ease with which phyllosilicates cleave into thin sheets. In micas, some $\mathrm{Si}$ atoms are replaced by $\mathrm{Al}$ atoms, thereby making a transition from a silicate to an aluminosilicate. $\mathrm{Al}$ and $\mathrm{Si}$ are adjacent to one another in the periodic table, and $\mathrm{Al}^{-}$is isoelectronic with Si. Starting with $\left[\mathrm{Si}_{4} \mathrm{O}_{10}\right]_{n}^{4 n-}$, replacement of one $\mathrm{Si}$ by Al leads to [AlSi $\left.\mathrm{O}_{10}\right]_{n}^{5 n-}$ which is found in muscovite mica, $\mathrm{KAl}_{2}\left(\mathrm{AlSi}_{3} \mathrm{O}_{10}\right)$ $(\mathrm{OH})_{2}$. There is no structural change on going from the $\left[\mathrm{Si}_{4} \mathrm{O}_{10}\right]_{n}^{4 n-}$ sheet in talc to the $\left[\mathrm{AlSi}_{3} \mathrm{O}_{10}\right]_{n}{ }^{5 n-}$ sheet in muscovite mica and so both can be represented by Fig. 4a, remembering that in the mica, one in four $\mathrm{Si}$ atoms is replaced by $\mathrm{Al}$. In muscovite mica, charge neutrality is attained by a combination of [AlSi $\left.\mathrm{O}_{30}\right]_{n}^{5 n-}$ and $\mathrm{OH}^{-}$with $\mathrm{K}^{+}$and $\mathrm{Al}^{3+}$ ions. Muscovite mica possesses the layered structure shown in Fig. 4b. Layers of $\mathrm{K}^{+}$or $\mathrm{Al}^{3+}$ ions separate adjacent aluminosilicate sheets, and $\mathrm{OH}^{-}$ions are located in the $\mathrm{Al}^{3+}$-containing layers. The material cleaves along the $\mathrm{K}^{+}$-containing planes (Fig. 4b) and Fig. 4c shows just how flaky micas are. Micas provide an excellent example of a structure-property relationship.

Weathering of silicate minerals in reactions with environmental $\mathrm{CO}_{2}, \mathrm{H}_{2} \mathrm{O}$ and $\mathrm{H}^{+}$releases silicic acid, $\mathrm{H}_{4} \mathrm{SiO}_{4}$. Condensation of the $\mathrm{H}_{4} \mathrm{SiO}_{4}$ molecules occurs with elimination of $\mathrm{H}_{2} \mathrm{O}$ leading to $\mathrm{Si}-\mathrm{O}-\mathrm{Si}$ bond formation (Eqn. 1) and ultimately to the assembly of amorphous silica $\left[\mathrm{SiO}_{n / 2}(\mathrm{OH})_{4-n}\right]_{m}$, also called opaline silica. Some marine organisms including unicellular algae possess exoskeletons comprised of biogenic silica and these intricate assemblies ${ }^{[3]}$ are constructed from $\mathrm{H}_{4} \mathrm{SiO}_{4}$ in sea water in a matter of days. When organisms with silica exoskeletons die, the
$\mathrm{Si}-\mathrm{O}-\mathrm{Si}$ bond formation is very slowly reversed, regenerating $\mathrm{H}_{4} \mathrm{SiO}_{4}$.

Some plants deposit biogenic silica in significant amounts and one characteristic example is the common horsetail (Equisetum arvense). The stems and branches (Fig. 5) are stiff and abrasive because of the presence of silica. The plants take up $\mathrm{H}_{4} \mathrm{SiO}_{4}$ through the roots when the $\mathrm{pH}$ is below $9,{ }^{[3]}$ and accumulate biogenic silica through the condensation reactions described above.
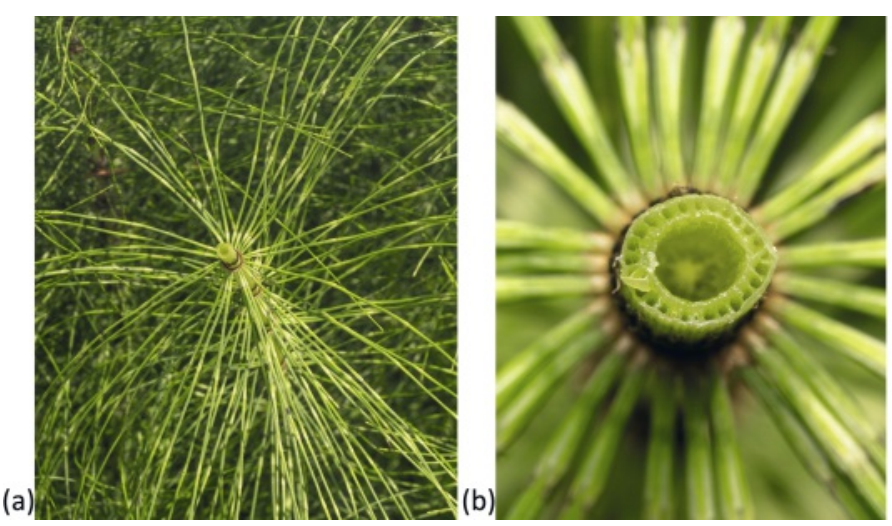

Fig. 5. (a) The fibrous stem and branches of the common horsetail, and (b) a close-up of the cut through the stem showing cellular structure. Credit: E. C. Constable 2020.

Careful treatment of the plant tissue with acid allows a fragile silicaceous framework to be isolated.

In summary, this article has illustrated some of the classes of silicate and aluminosilicate minerals and has shown how the structural features affect the habit (e.g. fibrous, lamellar) of the mineral. Slow weathering of silicates releases silicic acid, and condensation processes in aqueous media produces biogenic silica.

Received: October 26, 2020

[1] C. E. Housecroft, Chimia 2020, 74, 735.

[2] Inorganic Crystal Structure Database (ICSD); https://icsd.products. fiz-karlsruhe.de

[3] P. Labun, D. Grulova, I. Salamon, F. Šeršen, Food Nutr. Sci. 2013, 4, 510.

This column is one of a series designed to attract teachers to topics that link chemistry to Nature and stimulate students by seeing real-life applications of the subject.<smiles>O[Si](O)(O)O[Si](O)(O)O[Si](O)(O)O[Si](O)(O)O</smiles> 